\title{
Bisnis Olah Raga: Peran Bauran Pemasaran Pada Keberhasilan Usaha
}

\author{
Irwan Setiawan $^{1 *}$ dan Harmon ${ }^{2}$ \\ ${ }^{1}$ Jurusan Administrasi Niaga, Politeknik Negeri Bandung, Indonesia \\ 2 Jurusan Administrasi Niaga, Politeknik Negeri Bandung, Indonesia
}

\begin{abstract}
:
As a big city, Bandung needs sports area and facilities. However, in fact, just a little land available to be utilized. Seeing this potential market, some people who are keen to catch this opportunity are competing to set up the necessary sports facilities for residents. Futsal is one of the most famous. As a new business model, management needs various tactics and strategies to attract customers such as marketing mix strategy, yet the suitable marketing mix for sports business is still undiscoverable. For that reason, this study tries to find the dominant marketing mix that determines the success of a sports business venture, especially futsal, using the quantitative descriptive method. Collecting data from a total sample of 62 business units scattered in Bandung, the data from this sample then processed by the regression testing. The results prove that not all variants of the marketing mix futsal determine business success, critical success factors futsal sports business is largely determined by the quality of the product (futsal field) and supporting accessories.
\end{abstract}

Keywords: sport business, futsal, marketing mix, business success

\section{Abstrak:}

Sebagai kota besar, Bandung memerlukan fasilitas olah raga, padahal lahan yang tersedia semakin sedikit. Melihat pasar cukup potensial, berbagai fasilitas olah raga yang dibutuhkan warga mulai didirikan, diantaranya sarana olah raga untuk futsal. Akibatnya futsal menjadi lahan bisnis baru dan potensial. Sebagai lahan bisnis yang baru, diperlukan berbagai taktik dan strategi, salah satu diantaranya mencari ataupun meneliti berbagai varian bauran pemasaran yang cocok agar bisnis olah raga futsal berhasil. Pada penelitian ini dianalisis bauran pemasaran yang dominan menentukan keberhasilan usaha bisnis olah raga futsal dengan metode deskriptif kuantitatif dan data diolah dengan regresi berganda. Dengan total sampel 62 unit usaha bisnis olah raga futsal yang tersebar di Kota Bandung, hasil penelitian ini membuktikan bahwa tidak semua varian bauran pemasaran menentukan keberhasilan bisnis futsal. Faktor penentu keberhasilan bisnis olah raga futsal sangat ditentukan oleh produk (kualitas lapangan futsal) dan asesoris pendukungnya.

Kata Kunci: bisnis olah raga, futsal, bauran pemasaran, keberhasilan usaha

\section{LATAR BELAKANG}

Kota Bandung semakin memiliki lahan yang sempit untuk aktivitas olah raga

\footnotetext{
*Email korespondensi:

Irwan Setiawan

irwan.setiawan1990@yahoo.com
}

warganya. Peluang ini ditangkap oleh pebisnis sebagai lapangan usaha baru dengan cara menyediakan berbagai sarana dan prasarana yang memadai dan lengkap, satu diantaranya adalah bisnis olah raga futsal.

Bisnis ini adalah salah satu bisnis yang sedang berkembang di Kota Bandung, 
total lapangan futsal ada 76 bisnis. Hasil survey menunjukkan bahwa rata-rata omzet bisnis olah raga futsal di Kota Bandung mencapai Rp 15 juta s/d Rp 90 juta per bulan untuk satu unit usaha, jumlah tenaga kerja yang diperlukan relatif sedikit, tidak memiliki dampak negatif dan tidak memerlukan pengawasan yang extra ketat. Hal inilah yang menjadikan bisnis olah raga futsal semakin menjadi menarik bagi wirausaha olah raga. Dari sisi teoritis, faktor penentu keberhasilan bisnis olah oleh raga futsal adalah ketersediaan bauran pemasaran, seperti ketersediaan produk, harga, lokasi, promosi, orang, sarana/bukti fisik, dan proses bisnisnya. Oleh karenanya diperlukan kajian tersendiri guna mengatahui fakta kebenaran dari bauran pemasaran mana yang dominan menentukan keberhasilan bisnis dalam lapangan olah raga futsal.

\section{KERANGKA TEORI Bauran Pemasaran Jasa}

Bauran pemasaran merupakan kumpulan alat pemasaran yang terorganisir dan terintegrasi dengan baik untuk mencapai tujuan pemasaran dengan efesien. (Kotler dan Armstrong, 2008: 62; Hurriyati, 2010: 48). Bauran pemasaran dalam bidang jasa meliputi product/produk, price/harga, place/tempat/lokasi, promotion/promosi, people/orang, physical evidence/sarana/bukti fisik dan process/proses (Zeithalm, Bitner and Gremler, 2006: 26; Festa, Teresa, Metallo, \& Festa, 2015; 1). Bauran pemasaran dikembangkan dengan berbagai varian tergantung kebutuhan usaha masingmasing dan bisa dijadikan strategi pemasaran yang dikombinasikan dengan faktor lain. Sebagai strategi, mengkomunikasikan bauran pemasaran dengan tujuan perusahaan, bagaimana praktiknya, proses dan orang yang akan mengerjakan menjadi dasar mencapai keberhasilan perusahaan (Martin \& Martin, 2009: 391). Ini telah dibuktikan oleh hasil penelitian Wongleedee (2015: 197) bahwa penggunaan bauran pemasaran menentukan perilaku calon konsumen dan pelanggan. Menggunakan bauran pemasaran hendaklah holistik (menyeluruh), pandangan menyeluruh namun tetap terintegrasi akan memudahkan tercapainya tujuan perusahaan. Kreutzer (2006:19) mengingatkan bahwa bauran pemasaran perlu dianggap sebagai konsep global untuk mencapai keunggulan kompetitif.

\section{Produk (Product)}

Produk (product) jasa merupakan sejumlah nilai yang ditawarkan kepada konsumen, ia tidak berwujud, tetapi dapat dirasakan dan dinikmati oleh konsumen (Lupiyoadi dan Hamdani, 2008: 70; Kotler dan Armstrong, 2008: 62; Hurriyati, 2010: 50). Sebagai produsen atau penyedia jasa perlu fokus pada kebutuhan dan keinginan konsumen (Abd, Faizah, Hassan, \& Asiah, 2016: 366). Ketepatan untuk memahami kebutuhan dan keinginan konsumen, akan membantu menentukan berbagai strategi pemasaran (Bennett, 1978: 151). Dalam bisnis olah raga futsal produk yang ditawarkan diantaranya berupa penyewaan lapangan futsal, sewa sepatu futsal, bola, makanan dan minuman sehat, mandi air hangat dan lapangan parkir yang aman.

\section{Harga (Price)}

Harga adalah jumlah uang yang harus dikeluarkan oleh konsumen untuk mendapatkan barang atau jasa tersebut (Kotler dan Armstrong, 2008: 63; Joshi, 2012: 19). Ada berbagai cara menetapkan harga jasa, diantaranya: 1 . Penetapan harga berdasakan biaya (cost-based pricing); 2 . Penetapan harga berdasarkan persaingan (competition-based pricing); 3. Penetapan harga berdasarkan permintaan (demandbased) (Zeithalm, Bitner and Gremler, 2006: 521). Penetapan harga yang hanya berdoman pada kesempatan (peluang yang ada) dan tidak memperhatikan harga normal di masyarkat, untuk jangka penjang berdampak merugikan perusahaan. Kruetzer (1998: 28) telah mengingatkan agar para pebisnis menghindari bertindak mengambil keuntungan jangka pendek. 


\section{Lokasi (Place)}

Bisnis futsal termasuk dalam bisnis jasa. Penyediaan tempat yang strategis sangat menentukan keberhasilan bisnis ini. Lokasi dalam bisnis futsal terkait pada bagaimana konsumen mudah memperoleh informasi dan mudah pula memperoleh tempat untuk berolah raga futsal serta berlokasi ditempat yang strategis (Lupiyoadi dan Hamdani, 2008; Kotler dan Armstrong, 2008). Untuk berhubungan dengan konsumennya, pebisnis olah raga futsal bisa melakukan beberapa interaksi, konsumen datang langsung ke tempat penyedia olah raga futsal atau sebaliknya dan konsumen melakukan interaksi via jasa perantara (Hurriyati, 2010).

\section{Promosi (Promotion)}

Kegiatan mengkomunikasikan tentang keunggulan, manfaat, spesifikasi produk dengan tujuan mempengaruhi pikiran dan perilaku konsumen, sehingga konsumen mau membeli dan menjadi pelanggan disebut promosi (Kotler dan Armstrong, 2008; Hurriyati, 2010). Promosi bertujuan agar konsumen menjadi tahu tentang semua produk yang tersedia dan kemudian konsumen mau melakukan pembelian (Joshi, 2012). Ada beberapa media promosi bisa digunakan untuk bisnis olah raga futsal seperti: word of mouth, sales promotion, public relation, mass selling, direct marketing dan media sosial.

\section{Orang (People)}

Orang yang dimaksudkan disini adalah para karyawan atau SDM (sumber daya manusia) yang dipakai menjalankan bisnis olah raga futsal. SDM merupakan faktor penting dalam proses mencapai daya saing dan peningkatan kinerja perusahaan (Davcik \& Sharma, 2016). SDM-lah yang melaksanakan bisnis sehari-hari, mereka mempengaruhi secara langsung persepsi konsumen baik tentang kualitas produk yang dihasilkan ataupun kualitas layanan yang dihasilkan (Payne, 2000; Zeithalm, Bitner and Gremler, 2006; Lupiyoadi dan Hamdani, 2008). Karenanya dalam menjalankan bisnis olah raga futsal, pemilihan SDM yang berkualitas sangat menentukan berhasil tidaknya bisnis olah raga futsal mencapai tujuannya.

\section{Sarana (Physical Evidence)}

Sarana fisik merupakan bukti fisik tempat dimana jasa diciptakan dan bisa langsung dinikmati oleh konsumen (Lupiyoadi dan Hamdani, 2008: Zeithaml, 2006). Dalam bisnis olah raga futsal, ada dua jenis bukti fisik, yaitu bukti fisik utama menentukan kualitas produk seperti: lapangan bola futsal, gawang dan pencahayaan, sirkulasi udara, bola futsal, kebersihan, kondisi bangunan, kenyamanan. Sedangkan yang kedua adalah bukti fisik pendukung atau fasilitas pendukung seperti: kamar ganti pakaian, tempat penonton, parkir dan asesories lapangan futsal.

\section{Proses (Process)}

Proses merupakan gabungan aktivitas yang terintegrasi, baik berupa keputusan, kebijakan, prosedur, mekanisme dan kebiasaan yang dilakukan oleh SDM perusahaan untuk menyajikan jasa sesuai kebutuhan konsumen dengan efisien (Payne, 2000; Hurriyati, 2010; Lupiyoadi dan Hamdani; 2008). Kolaborasi disemua fungsi bisnis penting dilakukan untuk keberhasilan bisnis (Esopo, Almquist, Esopo, \& Almquist, 2012: 122). Para pengelola bisnis futsal, sebaiknya menyediakan lapangan yang memenuhi standar kesehatan baik cahaya, udara, kesehatan, kebisingan, kenyamanan dan rasa aman pengguna dan ketepatan, mekanisme pemesanan yang memudahkan serta kepastian waktu penggunaan. Jangan sampai terjadi ketika konsumen akan menggunakan fasilitas yang ada tidak berfungsi atau masih digunakan oleh konsumen lain.

\section{Keberhasilan Usaha}

Setiap bisnis mempunyai tujuan utama dan tujua lain. Tujuan utama orang melakukan bisnis adalah mendapatkan laba, tumbuh dan berkembang. Tujuan lain dari 


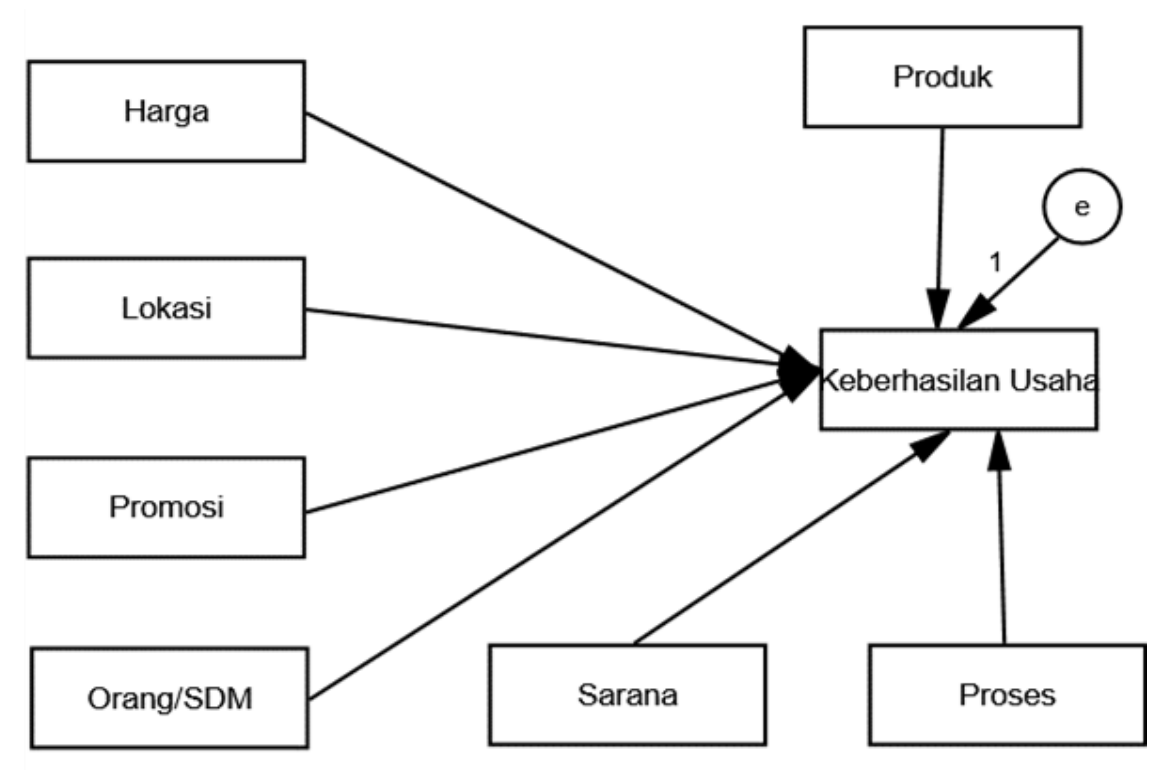

\section{Gambar 1 Model Penelitian}

bisnis sangat ditentukan oleh keinginan pemilik atau pemegang sahamnya. Beberapa tujuan lain dari bisnis adalah: membuka lapangan kerja, memenuhi kebutuhan masyarakat lokal dengan harga standar, menjaga stabilitas harga, menyehatkan masyarakat dan lainnya. Noor (2008) menyatakan "Keberhasilan usaha pada hekekatnya keberhasilan perusahaan dalam mencapai tujuannya". Tujuan yang dimaksud disini termasuk tujuan utama dan tujuan pendukung. Agar perusahan berhasil, pengelola bisnis hendaklah fokus mencapai tujuan, karena tujuan merupakan alat ukur keberhasilan aktivitas perusahaan (Griffin dan Ebert, 2007; Soegoto, 2009). Keberhasilan usaha bisnis olah raga futsal ditentukan oleh tujuan utama seperti: laba yang diperoleh, produktivitas, daya saing dan tujuan lain berupa manfaatnya bagi masyarakat. Dalam praktik, keberhasilan sebuah bisnis tidak hanya ditentukan oleh penggunaan bauran pemasaran, tetapi juga ditentukan oleh faktor-faktor lain. Martin \& Martin (2009: 294) menyebutkan bahwa kepribadian, gaya, kompetensi dari pemilik dan pengelola bisnis adalah menentukan keberhasilan usaha. Para pengusaha dituntut untuk selalu berkreasi, berinovasi dan lentur menggunakan strategi bauran pemasaran yang terintegrasi dalam mencapai tujuan perusahaan.

\section{METODE PENELITIAN}

Penelitian menggunakan metode deskriptif kuantitatif, analisis data menggunakan uji mean dan regresi berganda. Variabel bauran pemasaran terdiri dari produk / product, harga / price, lokasi / place, promosi / promotion, orang / people, sarana / bukti fisik / physical evidence, dan proses / process (Zeithalm, Bitner and Gremler, 2006: 26; Festa, Teresa, Metallo, \& Festa, 2015; 1). Sedangkan variabel keberhasilan usaha terdiri dari laba, omset, daya saing dan manfaat bagi lingkungan.

Populasi penelitian terdiri dari seluruh unit usaha yang bergerak dalam bisnis olah raga futsal di Kota Bandung. Total populasi pada tahun 2015 ada 76 unit usaha, jumlah sampel 62 unit usaha futsal atau $82 \%$ dari total pupulasi. Jumlah sampel demikian dianggap sudah layak, karena menurut Roscoe (dalam Sugiyono, 2012: 91), sampel yang layak untuk unit usaha (bukan orang) berada pada rentang 30 unit usaha s/d 500 unit usaha. Sampel diambil secara random dan data diperoleh dengan mengedarkan kuesioner pada masing-masing pengelola bisnis lapangan olah raga futsal 
yang tersebar di Kota Bandung. Kuesioner telah di uji validitas dan reliabilitasnya, hasil pengujian semua variabel valid dan data yang diperoleh memiliki reliabilitas di atas 0,7 (0,854 untuk Bauran Pemasaran dan 0,8666 untuk Keberhasilan Usaha) atau layak digunakan dalam penelitian ini. Keterkaitan antar variabel penelitian seperti Gambar 1 .

\section{PEMBAHASAN}

\section{Analisis Bauran Pemasaran Jasa}

Bauran pemasaran (marketing mix) merupakan unsur-unsur pemasaran yang saling terintegrasi, terkoordinasi dan digunakan dengan tepat, sehingga perusahaan mencapai tujuannya. Agar bisnis yang dijalankan mencapai tujuan, maka setiap bisnis memiliki kebijakan bauran pemasaran tersendiri, termasuk juga bisnis olah raga futsal. Dalam praktik bauran pemasaran ditentukan oleh kreaktivitas, fleksibilitas dan inovasi hari-hari pengelola bisnis dan para pengusaha biasanya punya trik (strategi) tersendiri, pengusaha dimungkinkan menggunakan berbagai taktik yang menyimpang dari penggunaan bauran pemasaran (Martin \& Martin, 2009: 391392). Hasil pengumpulan dan pengolahan data bisnis dilapangan, memberikan gambaran kesadaran pelaku bisnis olah raga futsal akan pentingnya bauran pemasaran dalam bisnis mereka, sehingga setiap pengambilan keputusan dan strategi bauran pemasaran, mereka lakukan dengan hati-hati dan cermat. Pengelola bisnis olah raga futsal membuat program pemasaran yang terdiri dari berbagai unsur, ini sebaiknya menjadi bahan pertimbangan agar implementasi strategi pemasaran dan positioning yang ditetapkan berjalan lancar (Lupiyoadi dan Hamdani, 2008: 70).

Faktor pertama dari bauran pemasaran yaitu produk. Produk adalah unsur bauran pemasaran yang paling mendasar dan akan menjadi perhatian utama konsumen, karena itu perlu fokus menyediakannya (Bennet, 1997: 151; Soegoto, 2009: 95; Abd et al., 2016, 366). Dalam bisnis futsal, produk terlihat dari beragam pilihan jenis permukaan lapangan futsal. Alternatif dalam penentuan produk (product) lapangan futsal diantaranya rumput sintetis, parquette (kayu), karet, teraflex, interlock bahkan semen sekalipun. Walaupun berbeda-beda dari segi permukaan lapangan dan ukuran di setiap bisnis lapangan futsal, tapi kualitas yang diberikan hendaklah berkualitas baik sesuai dengan keinginan konsumen. Hal inilah yang membedakan antara setiap bisnis lapangan futsal, karena kebutuhan dan keinginan masyarakat akan lapangan futsal tidaklah sama. Produk perlu diperhatikan karena konsumen tidak hanya membeli fisik dari produk itu saja tetapi membeli manfaat dan nilai dari produk tersebut (Lupiyoadi dan Hamdani, 2008: 70). Para pelaku bisnis lapangan futsal sadar betul bahwa lapangan futsal yang disediakan haruslah diperhatikan dengan baik karena menjadi dasar bagi perusahaan dalam membangun hubungan yang menguntungkan dengan konsumen. Kotler dan Armstrong (2008: 267), mengingatkan bahwa produk adalah elemen kunci dalam keseluruhan penawaran pasar yang menjadi dasar percaya tidaknya konsumen pada produk/jasa yang ditawarkan.

Faktor yang kedua yaitu harga, adalah jumlah uang yang harus dikeluarkan konsumen agar bisa menikmati produk yang diinginkannya. Penentuan harga dilakukan dengan hati-hati, harga yang terlalu tinggi bisa berakibat pindahnya konsumen pada tempat lain, namun harga yang terlalu murah juga akan mendatangkan keraguan kualitas produk yang ditawarkan. Mencari keuntungan yang besar untuk jangka pendek hendaknya dihindari (Kreutzer, 2006). Harga yang ditawarkan setiap lapangan futsal di Kota Bandung sangatlah bervariasi di setiap lokasi dari mulai Rp.60.000 sampai dengan lebih dari Rp. 160.000 per jamnya. Strategi penentuan harga sangat signifikan menentukan nilai kepada konsumen dan mempengaruhi citra produk, serta keputusan konsumen untuk membeli (Lupiyoadi dan Hamdani, 2008: 72). Hal ini sangat disadari oleh pelaku usaha bisnis lapangan futsal, 
kebanyakan usaha futsal mengambil kebijakan harga sewa lapangan futsal melihat harga pesaing (competition-based pricing).

Faktor ketiga yaitu lokasi yaitu tempat dimana konsumen yang akan menggunakannya mudah melaksanakan aktivitas futsal. Lokasi bisnis lapangan futsal hendaknya berada di lokasi yang strategis, mudah dijangkau konsumen. Rata-rata lokasi futsal di Kota Bandung berada dilokasi yang jumlah penduduknya padat dan strategis. Penempatan lokasi yang strategis akan memudahkan interaksi antara konsumen dengan pengelola futsal, sehingga pengelola lebih mudah mempengaruhi keinginan konsumen.

Faktor keempat adalah promosi, merupakan aktivitas menyampaikan keungulan tentang produk bila dibandingkan dengan tempat lain pada konsumen. Beberapa kegiatan promosi yang dilakukan adalah memasang informasi di spanduk, pemberitahuan ditempat stategis, mengadakan demo atau event tertentu tentang olah raga futsal, sales promotion, dan iklan di media cetak atau media sosial. Contoh kegiatan sales promotion adalah pemberian harga khusus bagi para member. Sales promotion adalah bentuk persuasif langsung melalui penggunaan berbagai insentif yang dapat diatur untuk merangsang pembelian produk dengan segera dan atau meningkatkan jumlah barang yang diberi (Hurriyati, 2010: 60). Selain itu, word of mouth (komunikasi dari mulut kemulut) pun berperan secara tidak langsung dalam kegiatan promosi di bisnis lapangan futsal, karena pelanggan seringkali memperhatikan dengan teliti penyerahan jasa dan kemudian menceritakan pengalamannya pada pelanggan potesial lainnya.

Faktor kelima yaitu orang seperti karyawan (SDM) penyedia jasa layanan maupun penjualan atau orang-orang yang terlibat secara langsung maupun tidak langsung dalam proses layanan itu sendiri sangat menentukan keberhasilan usaha (Martin \&Martin, 2009: 294; Sukotjo dan Radix, 2010: 219). People bukan hanya memegang peranan penting dalam bidang produksi atau operasional saja, tetapi juga dalam melakukan hubungan kontak langsung dengan konsumen, oleh karena itu karyawan hendaklah dipilih dengan kriteria tertentu, bukan saja dari aspek keterampilan tetapi juga aspek softskill (aspek kejujuran, keramahan, kesabaran dan kemauan melayani). Orang yang terlibat di setiap bisnis lapangan futsal tidak perlu berjumlah banyak, ini tergantung dari skala usahanya, biasanya hanya melibatkan kurang dari 5 orang yang terdiri dari koordinator, petugas penyewaan lapang, petugas kebersihan, petugas parkir dan petugas keamanan. Tugastugas tersebut dapat dirangkap oleh SDM pengelola bisnis futsal.

Faktor keenam yaitu sarana/bukti fisik merupakan lingkungan fisik tempat jasa tersedia. Beberapa sarana fisik yang diperlukan pada bisnis olah raga futsal adalah kebersihan lingkungan sekitar, kondisi bangunan, kerampihan, fasilitas-fasilitas pendukung, dan kuitansi pembayaran. Terkadang bagi konsumen menengah ke atas secara ekonomi, lingkugan fisik ini menjadi penentu yang bersangkutan untuk mau menjadi konsumen.

Faktor ketujuh adalah proses, merupakan gabungan semua aktivitas bisnis lapangan futsal yang terintegrasi mulai dari awal sampai berakhirnya konsumen menikmati jasa lapangan futsal. Contoh proses dalam bisnis lapangan futsal seperti pemesanan dan pembayaran sewa lapang. Mekanisme pemesanan untuk penyewaan lapangan dilakukan dengan membayar separuh dari harga sewa saat melakukan booking dan pelunasan pembayaran dilakukan setelah jam sewa secara tunai. Proses dalam jasa merupakan faktor utama dalam bauran pemasaran jasa, ia bagian dari jasa itu sendiri. Pentingnya elemen proses ini disebabkan dalam bisnis jasa persediaan jasa tidak dapat disimpan (Hurriyati, 2010: 64).

\section{Analisis Keberhasilan Usaha}

Data lapangan menunjukkan rata-rata unit usaha futsal yang memiliki produk 
(lapangan futsal) berkualitas dan terletak di tempat strategis dengan harga bersaing selalu ramai dan mencapai target laba, omset bahkan tumbuh dan mengembangkan usahanya. Jam operasional dalam satu hari 18 jam, namun efektif operasionalnya 12 jam perhari. Mayoritas dari unit usaha futsal dimiliki oleh swasta/orang individu. Beberapa diantara pebisnis lapangan olah raga futsal telah menyelenggarakan kegiatan yang bermanfaat bagi masyarakat, seperti: lomba futsal untuk warga sekitar, menjadi donatur kegiatan warga dan sponsor pada event sosial lainnya.

Tabel 1 Total Pengaruh Bauran Pemasaran pada Keberhasilan Usaha

\begin{tabular}{|c|c|c|c|c|}
\hline $\mathbf{R}$ & $\begin{array}{c}\mathbf{R} \\
\text { Square }\end{array}$ & $\begin{array}{c}\text { Adj. } \mathbf{R} \\
\text { Square }\end{array}$ & $\begin{array}{c}\text { Std. } \\
\text { Error }\end{array}$ & $\begin{array}{c}\text { Sig. F } \\
\text { Change }\end{array}$ \\
\hline 0,627 & $\mathbf{0 , 3 9 3}$ & 0,315 & 5,4928 & 0,000 \\
\hline
\end{tabular}

\section{Pengaruh Bauran Pemasaran Jasa Pada Keberhasilan Usaha Bisnis Olah Raga Futsal}

Hasil pengolahan data diperoleh informasi seperti pada tabel 1, nilai koefisien determinasi atau R-Square yang diperoleh adalah sebesar 0,393 atau 39,3\% dengan tingkat signifikansinya $0,00 . \quad$ Hal ini menunjukkan bahwa bauran pemasaran untuk bisnis olah raga futsal terbukti secara signifikan memberikan kontribusi pengaruh sebesar 39,3\% terhadap keberhasilan usahanya.
Sedangkan pengaruh secara partial (masing-masing faktor) ditunjukkan oleh tabel 2. Berdasarkan tabel 2 diketahui bahwa faktor dari bauran pemasaran jasa yang dominan dan signifikan mempengaruhi keberhasilan usaha adalah faktor produk yang ditunjukkan dengan pengaruh sebesar $15,1 \%$. Sedangkan faktor lain seperti harga, lokasi, promosi, orang, sarana/bukti fisik, dan proses belum ada bukti memiliki pengaruh pada keberhasilan usaha olah raga futsal. Berpengaruhnya faktor produk pada keberhasilan bisnis futsal disebabkan konsumen menyukai lapangan futsal yang akan disewa berkualitas, nyaman dan aman, konsumen menyukai saat bermain futsal mereka aman dan terhindar dari cedera yang diakibatkan kualitas lapangan yang buruk.

Berdasarkan hasil pengujian pada tabel 1 diketahui bahwa nilai koefisien determinasi atau R-Square yang diperoleh adalah sebesar 0,393 atau 39,3\%. Artinya secara bersama-sama faktor bauran pemasaran tersebut memili efek terhadap keberhasilan usaha sebesar 39,3\%, namun secara partial (individual), hanya faktor produk yang terbukti berpengaruh (lihat tabel 2).

Hasil penelitian ini membuktikan bahwa bauran pemasaran (marketing mix) merupakan unsur-unsur internal penting yang membentuk program pemasaran sebuah organisasi bisnis. Tujuh bauran pemasaran yang digunakan pada bisnis jasa olah raga futsal, seperti produk / product, harga / price,

Tabel 2 Pengaruh Parsial Bauran Pemasaran pada Keberhasilan Usaha

\begin{tabular}{|l|r|r|r|r|}
\hline \multicolumn{1}{|c|}{ Dimensi } & \multicolumn{1}{c|}{ Koefisien } & Korelasi & $\begin{array}{c}\text { Pengaruh } \\
\text { Parsial }\end{array}$ & Tk. Signifikan \\
\hline Produk & 0,3 & 0,502 & $\mathbf{0 , 1 5 1}$ & 0,029 \\
\hline Harga & 0,043 & 0,386 & $\mathbf{0 , 0 1 7}$ & 0,753 \\
\hline Lokasi & 0,14 & 0,344 & $\mathbf{0 , 0 4 8}$ & 0,233 \\
\hline Promosi & 0,168 & 0,42 & $\mathbf{0 , 0 7 1}$ & 0,174 \\
\hline Orang & $-0,025$ & 0,322 & $\mathbf{- 0 , 0 0 8}$ & 0,855 \\
\hline Sarana/Bukti Fisik & 0,12 & 0,35 & $\mathbf{0 , 0 4 2}$ & 0,376 \\
\hline Proses & 0,196 & 0,374 & $\mathbf{0 , 0 7 3}$ & 0,149 \\
\hline \multicolumn{2}{|r|}{ Total Pengaruh } & & $\mathbf{0 , 3 9 3}$ & $\mathbf{0}$ \\
\hline
\end{tabular}


lokasi / place, promosi / promotion, orang / people, sarana / bukti fisik / physical evidence, dan proses / process tidak semuanya terbukti mempengaruhi keberhasilan usaha.

Penjelasan yang bisa disampaikan bahwa bauran pemasaran memiliki hubungan dan pengaruh terhadap keputusan pelanggan, kepuasan pelanggan, hingga loyalitas pelanggan karena setiap faktor dari bauran pemasaran yang ditawarkan dinilai akan berdampak terhadap terpenuhinya kebutuhan dan keinginan pelanggan yang bervariasi. Adanya transaksi antara pelanggan dengan perusahaan menumbuhkan produktivitas usaha yang meliputi omzet, volume penjualan dan jumlah pelanggan. Besar kecilnya omset suatu usaha akan sangat menentukan besar kecilnya produktivitas perusahaan. Hal ini akan mempengaruhi besar kecilnya penjualan dan pada akhirnya menentukan besar kecilnya pendapatan, sehingga mempengaruhi besar kecilnya laba yang diperoleh serta daya saing perusahaan (Noor, 2008: 397). Produktivitas yang baik ditunjukkan oleh tingkat laba yang diperoleh perusahaan. Tujuan utama dari bisnis adalah menjalankan usaha untuk memperoleh laba. (Soegoto, 2009: 18).

Menurut Basri (2005: 7), tujuan dari bisnis meliputi mencari laba jangka panjang, mempertahankan dan mengembangkan kehidupan organisasi, memenuhi kebutuhan barang dan jasa masyarakat serta memberi bantuan (sebagai tanggung jawab sosial bisnis) dan dapat memperkuat ketahanan negara (dari pajak, penarikan tenaga kerja, devisa dan sebagainnya). Keberhasilan usaha adalah tercapainya tujuan perusahaan secara sempurna.

Dalam mencapai keberhasilan usaha terdapat kunci sukses meliputi kepribadian, gaya, kompetensi/skill pemilik/pengelola, modal, marketing mix (Martin \& Martin, 2009: 294; Soegoto, 2009: 51). Hasil penelitian Purwanto (2007: 118), membuktikan ada beberapa faktor yang mendukung keberhasilan usaha diantaranya: faktor kemajuan usaha, meliputi kelengkapan produk, harga murah, perputaran modal, dan ambil untung sedikit; faktor sistem pelayanan yang baik, meliputi sikap terbuka menerima kritik dan saran, keramahan karyawan, menerima barang kembali jika terjadi kerusakan, kemampuan karyawan memberikan kejelasan mengenai barang yang ditawarkan dan memberikan jasa tepat waktu; faktor sikap mental wiraswasta, meliputi ketekunan dalam usaha dan keberanian mengambil resiko; faktor ketepatan memilih lokasi, meliputi lokasi terletak di arus bisnis, mudah dijangkau dan parkir aman serta faktor pemberian bonus.

Sebagian besar faktor-faktor tersebut merupakan bagian dari bauran pemasaran jasa. Selain itu, dari hasil penelitian Indriyatni (2013: 69) menyimpulkan bahwa ada faktor dari bauran pemasaran yang memiliki pengaruh signifikan terhadap keberhasilan usaha yaitu lokasi. Sedangkan pada hasil penelitian ini faktor bauran pemasaran jasa yang memiliki pengaruh dominan dan signifikan terhadap keberhasilan usaha bisnis lapangan fusal di Kota Bandung hanya faktor produk dengan pengaruh sebesar $15,1 \%$ yang dapat dilihat pada tabel 2. Hal ini karena konsumen melihat lapangan futsal yang akan disewa haruslah berkualitas agar saat bermain futsal terasa nyaman dan terhindar dari resiko jatuh, keseloa, cedera lain yang diakibatkan kualitas lapangan buruk. Kotler dan Armstrong (2008: 267) telah mengingatkan bahwa produk adalah elemen kunci dalam keseluruhan penawaran pasar yang menjadi dasar bagi perusahaan membangun hubungan positif dengan pelanggan. Konsumen membeli sebuah produk bukan hanya sekedar menikmati produk tersebut tetapi juga untuk memenuhi kebutuhan dan keinginan konsumen (Sukotjo dan Radix, 2010: 219). Konsumen tidak hanya membeli fisik dari produk itu saja tetapi membeli manfaat dan nilai dari produk tersebut. Terutama pada produk jasa yang kita kenal tidak menimbulkan beralihnya kepemilikan dari penyedia jasa kepada konsumen (Lupiyoadi dan Hamdani, 2008: 70). Hal ini karena jasa 
merupakan sesuatu tidak berwujud dan cepat hilang, lebih dapat dirasakan dari pada dimiliki serta pelanggan lebih mudah berpartisipasi dalam proses mengkonsumsi jasa tersebut (Hurriyati, 2010: 50). Whalley (2010: 92) menyebutkan segala sesuatu yang memberikan kepuasan terhadap kebutuhan konsumen adalah produk.

Penelitian ini mirip hasil penelitian Hutabarat (2006) yang menemukan bahwa prioritas bauran pemasaran adalah produk, namun berbeda dengan temuan Indriyani (2013) yang menyimpulkan bahwa lokasi yang menentukan keberhasilan usaha. Penjelasan yang bisa diberikan ini disebabkan adanya perbedaan obyek penelitian dan waktu.

\section{KESIMPULAN}

Meskipun terdapat banyak varian bauran pemasaran, namun tidak semua varian tersebut berpengaruh pada keberhasilan bisnis olah raga futsal. Penelitian membuktikan hanya faktor produk yang mempengaruhi sukses tidaknya usaha bisnis di bidang futsal. Sedangkan faktor lain atau varian lain dari bauran pemasaran perlu diteliti lebih lanjut adalah dari sisi area dan subjek yang berbeda serta dilihat juga dari sisi personality trait pengelola dan budaya masyarakat.

\section{DAFTAR PUSTAKA}

Abd, N., Faizah, L., Hassan, A., \& Asiah, S. (2016). The Relationship Between Marketing Mix And Customer Loyalty In Hijab Industry: The Mediating Effect Of Customer Satisfaction. Procedia Economics and Finance, 37(16), 366371. https://doi.org/10.1016/S22125671(16)30138-1

Bennett, A. R. (1978). The five Vs - a buyer's perspective of the marketing mix, (1966), 151-156.

Davcik, N. S., \& Sharma, P. (2016). Marketing resources, performance, and competitive advantage: A review and future research directions. Journal of Business Research, 69(12), 5547-5552. https://doi.org/10.1016/j.jbusres.2016.04 .169

Esopo, M. D., Almquist, E., Esopo, M. D., \& Almquist, E. (2012). An approach to mastering the marketing mix, 8 No. 2 , 122.

https://doi.org/10.1108/17515630710685 186

Festa, G., Teresa, M., Metallo, G., \& Festa, A. (2015). The ( $r$ ) evolution of wine marketing mix : From the 4Ps to the 4Es it. Journal of Business Research, (JBR08583), 6. https://doi.org/10.1016/j.jbusres.2015.10 .015

Griffin, R. W., \& Ebert, R. J. (2006). Bisnis (edisi 8). Terjemahan oleh Wardhani, Sita. Jakarta: Penerbit Erlangga.

Hurriyati, R. 2010. Bauran Pemasaran Jasa dan Loyalitas Konsumen. Bandung: Alfabeta

Hutabarat, L. M. (2006). Analisis bauran pemasaran restoran pizza (studi kasus di Pizza Hut Padjajaran 29 di Kota Bogor). Diambil 7 Agustus 2014 dari http://www.share pdf.com/c9c26ae2dbe445ec818b9292c4 b19bfe/H06lmh.htm

Indriyatni, L. (2013). Analisis faktor-faktor yang berpengaruh terhadap keberhasilan usaha mikro dan kecil. Jurnal STIE Semarang. 5 (1). 54-70.

Joshi, M. (2012). Essential of Marketing. Dalam bookboon diambil 4 Mei 2014 dari http://www.bookboon.com

Kotler, P., \& Armstrong, G. (2008). PrinsipPrinsip Pemasaran (edisi 12). Terjemahan oleh Sabran, Bob. 2008. Jakarta: Erlangga.

Kreutzer, R. T. (2006). Marketing-Mix Standardisation : An Integrated Approach in Global Marketing. European Journal of Marketing, 22(10), 19-30.

Lupiyoadi, R., \& Hamdani, A. (2008). Manajemen Pemasaran Jasa. Jakarta: Salemba Empat.

Martin, D. M., \& Martin, D. M. (2009). The entrepreneurial marketing mix. Qualitative Market Research: An 
International Journal, 12 No.4, 391-403. https://doi.org/10.1108/13522750910993 310

Noor, H. F. (2008). Ekonomi Manajerial. Jakarta: Raja Grafindo Persada.

Payne, A. 1993. Pemasaran Jasa. Terjemahan oleh Fandy Tjiptono. 2000. Yogyakarta: Andi.

Purwanto, A. B. (2007). Analisis faktorfaktor pendukung keberhasilan usaha elektronik di Kota Semarang. Fokus Ekonomi. 2 (2). 107-119.

Soegoto, E. S. (2009). Entrepreneurship Menjadi Pebisnis Ulung. Jakarta: Elex Media Komputindo.

Sugiyono. (2012). Metode Penelitian Kuantitatif, Kualitatif dan $R \& D$. Bandung: Alfabeta.

Sukotjo, H., \& Sumanto, R. A. (2010). Analisa marketing mix-7P (produk, price, promotion, place, partisipant, processs, dan physical evidence) terhadap keputusan pembelian produk klinik kecantikan teta dai Surabaya. Jurnal Mitra Ekonomi dan Bisnis, 1 (2). 216228.

Whalley, A. (2010). Strategic Marketing (1st edition). Dalam bookboon diambil $4 \mathrm{Mei}$ 2014 dari http://www.bookboon.com

Wongleedee, K. (2015). Marketing Mix and Purchasing Behavior for Community Products at Traditional Markets. Procedia - Social and Behavioral Sciences, 197 (February), 2080-2085. https://doi.org/10.1016/j.sbspro.2015.07. 323

Zeithalm, A. V., Bitner, M. J., \& Gremler, D. D. (2006). Service Marketing. New York: Mc Graw-Hill 